\title{
CPC DA UNE: ENGAJAMENTO, ROMANTISMO REVOLUCIONÁRIO E LITERATURA (1961-1964)
}

\author{
UNE'S CPC: ENGAGEMENT, REVOLUTIONARY ROMANTICISM AND \\ LITERATURE (1961-1964)
}

Reginaldo Sousa Chaves*

\begin{abstract}
RESUMO
O presente artigo tem como objetivo discutir a produção poética ligada ao Centro Popular de Cultura da União Nacional dos Estudantes (CPC da UNE), criado em 1961. Abordamos o discurso literário cepecista a partir de uma discussão sobre as temporalidades que emergem das poesias reunidas nos livros da coleção Violão de Rua, publicada entre 1962 e 1963 pelo órgão cultual da UNE. Buscamos mostrar como essa escrita poética, ao articular passado, presente e futuro, acaba por situar-se entre a nostalgia e a expectativa de transformações sociais. O romantismo revolucionário cepecista construiu uma imaginação temporal baseada na saudade de um povo detentor da essência da nacionalidade brasileira, mas também vislumbrava, nesse mesmo povo, o heroico portador da revolução por vir.
\end{abstract}

PALAVRAS-CHAVE: $C P C$ da UNE. Engajamento. Temporalidade.

\begin{abstract}
This article aims to discuss the poetic production related to the Popular Culture Center of the National Students Union (UNE's CPC) created in 1961. We approach the cepecist literary discourse based on a discussion about the temporalities that emerge from the poems gathered in the books from the collection Violão de Rua (Street Guitar), published between 1962 and 1963 by the cultural branch of UNE. We seek to show how this poetic writing, when articulating past, present and future, ends up being situated between nostalgia and the expectation of social changes. The revolutionary romanticism cepecist builds a temporal imagination based on the longing for people who holds the essence of Brazilian nationality, but it also realized, about that same people, the heroic bearer of the revolution to come.
\end{abstract}

KEYWORDS: UNE's CPC. Engagement. Temporality.

\section{INTRODUÇÃO}

O Partido Comunista Brasileiro (PCB), no início da década de 1960, mantinha em torno de si, sob a forma de oposição ou adesão, o debate sobre as possibilidades de uma prática política militante. As orientações partidárias não deixavam de repercutir junto aos intelectuais que lhe eram próximos. Não

\footnotetext{
* Professor da Universidade Estadual do Piauí (UESPI). Doutor em História Social pela Universidade Federal do Ceará (UFC). E-mail: reginaldocioran29@gmail.com
} 
se tratava, contudo, de mera reprodução ideológica. Ao contrário, existiam apropriações tão diversificadas quanto as formas de engajamento. O que implica na necessidade de leitura atenta das descontinuidades entre as obras artísticas ditas participantes e o programa do partido e das demais instituições ligadas às esquerdas. Uma das mais influentes diretrizes partidárias era uma ideia compartilhada com outras instituições e que também tinham importante eco no meio cultural brasileiro. Referimo-nos à chamada "razão dualista", elaborada pelo Instituto Superior de Estudos Brasileiros (ISEB), a Comissão Econômica para a Americana Latina (Cepal) e o próprio PCB (OLIVEIRA, 2013).

Essa tese "concebia a sociedade brasileira cindida em duas: a moderna, em franco desenvolvimento, conviveria com um Brasil atrasado e subdesenvolvido." Entre os comunistas do PCB essa concepção se traduzia na pressuposição de que

[...] haveria resquícios feudais ou semifeudais no campo, a serem removidos por uma revolução burguesa, nacional e democrática, que uniria todas as forças interessadas no progresso da nação e na ruptura com o subdesenvolvimento (a burguesia, o proletariado, setores das camadas médias e também os camponeses) (RIDENTI, 2010, p. 123-124).

Um posicionamento que foi caraterizado como "forte em anti-imperialismo e fraco na propaganda e organização da luta de classes" (SCHWARZ, 2008, p. 73). De acordo com essa perspectiva, a luta deveria ser travada contra "o imperialismo e seus aliados internos, os latifundiários e os setores das camadas médias próximas dos interesses multinacionais." Apenas depois da revolução "antiimperialista, antifeudal, nacional e democrática" viria a segunda fase revolucionária (RIDENTI, 2010, p. 124).

Essa temporalidade futurista, com a linha de chegada utópica sendo conquistada por etapas, não foi deslocada intacta para o campo artístico-cultural. Nesse diálogo, a proposição de um regime de organização das relações entre passado, presente e futuro revolucionário foi muitas vezes retraduzido pelos intelectuais dedicados às produções estéticas (HARTOG, 2015, p. 11). Com efeito, o Centros Popular de Cultura da União Nacional dos Estudantes (CPC da UNE) mostra essa complexidade na relação entre fatura artística e programa das esquerdas.

Nesse sentido, o objetivo de nosso artigo é discutir a produção literária desse órgão de produção cultural de esquerda e abordar alguns aspectos da temporalidade artística cepecista. Procuramos mostrar que alguns escritores cepecistas, ao incorporarem elementos da moderna tradição do romantismo revolucionário, construíram uma composição temporal que extrapola a noção de linha temporal progressista e revolucionária. Nessa imaginação temporal, passado e futuro despertam sensibilidades nostálgicas e expectativas de transformações sociais.

Assim, para cumprir nosso objetivo, elaboramos nosso percurso em quatro momentos. Primeiramente, discutimos brevemente o processo de criação do CPC da UNE, no Rio de Janeiro. Em seguida, tratamos dos conflitos e disputas intelectuais que ocorreram no processo de construção das atividades desse órgão cultural de esquerda. Demos ênfase às disputas entre o ideólogo Carlos Estevam e os diretores do chamado cinema novo. A compreensão da imaginação temporal cepecista passa pela 
discussão protagonizada por essa intelectualidade em torno de temas decisivos para a época: arte engajada, forma, conteúdo, povo e revolução.

$\mathrm{Na}$ terceira parte de nosso texto, abordamos as noções de romantismo e romantismo revolucionário e o modo como o pesquisador Marcelo Ridenti as mobiliza para a compreensão das esquerdas brasileiras da década de 1960. Veremos que sua abordagem é fundamental para entendermos em que consistem as particularidades que irrompem no tempo da revolução nostálgica e progressista da poesia cepecista. Por fim, para flagrar de perto as temporalidades romântico-revolucionárias, realizamos a leitura histórica de alguns poemas engajados da coleção Violão de Rua, do CPC da UNE, publicados entre 1962 e 1963. É neles que encontramos oportunamente explicitadas a imaginação temporal da escrita poética cepecista.

\section{O NACIONAL-POPULAR: O SURGIMENTO DO CPC}

Antes de 1964, o "projeto político-cultural do Partido Comunista estava ancorado na grande aliança de classes marcada pela cultura nacional-popular" (NAPOLITANO, 2013, p. 326). Nesse sentido, a questão “quem é o povo no Brasil?” ganhou grande destaque no início da década de 1960. Tratava-se de identificar os limites da nacionalidade brasileira e de engastá-la no seu povo em vias de revolucionar-se. O intelectual Nelson Werneck Sodré, ligado ao ISEB e ao PCB, propôs a seguinte reposta: "o conjunto das classes, camadas e grupos sociais empenhados na solução objetiva das tarefas do desenvolvimento progressista e revolucionário na área em que vive." O que incluiria "o campesinato, o semiproletariado, o proletariado; a pequena burguesia e as partes da alta e média burguesia que têm seus interesses confundidos com o interesse nacional e lutam por este” (SODRÉ, 1962, p. 36-37).

Estavam fora dessa noção de povo os grandes latifundiários e setores da "alta" burguesia antinacionalista, duas classes que se supunham ligadas aos interesses estrangeiros e imperialistas. Essa compreensão foi reinterpretada por diversos grupos culturais ligados às esquerdas. Em resumo, estava em vigência um vago imaginário de uma revolução nacional, popular e anti-imperialista. Essa ideia, que acarretou a chamada "ida ao povo", encontrou diferentes meios de expressão na esfera artística.

No campo teatral essa problemática se esboçava desde o final da década de 1950 com o Teatro de Arena. Surgido em São Paulo a partir do rompimento com o Teatro Brasileiro de Comédia (TBC), o grupo adquiria uma face mais engajada ao reunir "jovens dramaturgos e atores, como Oduvaldo Vianna Filho, Gianfrancesco Guarnieri e Flávio Migliacio, entre outros” (NAPOLITANO, 2001, p. 27). A eles se junta, em julho de 1956, o teatrólogo Augusto Boal, que promove os Seminários de Dramaturgia , nos quais se discutia as linhas artístico-políticas da atuação teatral.

No Arena, a renovação política das temáticas, interpretações e montagens teve como um dos seus momentos fundamentais a encenação da peça de Gian Francesco Guarnieri, Eles não usam black-tie (1958), drama popular sobre trabalhadores urbanos. No ano seguinte, Guarnieri publicaria o artigo "O teatro como expressão da realidade nacional", em defesa da "obra dos novos autores" brasileiros e da 
urgência da abordagem "de temas sociais, problemas do nosso povo" (GARCIA, 2007, p. 23). São dessa mesma época as reflexões afins de Vianinha, que defendiam uma prática teatral que assumisse "o ponto de vista das classes subalternas", opondo dois teatros: o esteticista do TBC e o de responsabilidade do Arena (BETTI, 1997, p. 36-37).

No início da década de 1960, a proposição de um teatro político e nacional chega a um momento de radicalização com relação ao seu público e o formato comercial. Além do texto de Guarnieri, as apresentações no Rio de Janeiro das peças Chapetuba F. C. (Oduvaldo Vianna Filho) e Revolução na América do Sul (Augusto Boal) consolidam a cisão dentro do Grupo Arena. Emergia, então, o processo de amadurecimento de uma linha de atuação protagonizada por aqueles que se preocupavam com uma dramaturgia que fosse autenticamente revolucionária.

Segundo Vianinha, o "Arena não atingia o público popular" e deixava de "mobilizar um grande número de ativistas." Formatado como "empresa", o grupo deixava de lado a "urgência de conscientização, a possibilidade de arregimentação da intelectualidade, dos estudantes, do próprio povo, a quantidade de público existente". O "Arena, sem contato com as camadas revolucionárias" da sociedade não armaria um "teatro de ação", mas apenas "um teatro inconformado" (PEIXOTO, 1983, p. 93). A linha divergente decide ficar na cidade do Rio de Janeiro e logo organizaria a montagem da peça de Vianinha, A mais valia vai acabar, seu Edgar. Carlos Lyra compôs as canções usadas na peça. Lyra, junto com outros artistas, como Sérgio Ricardo, Sidney Miller e Geraldo Vandré, deu início à música nacionalista e engajada que marcaria oposição cerrada, nos anos 1960, ao rock da Jovem Guarda e, depois, também contra o Tropicalismo.

Como o título da peça indica, havia a pretensão de expor ao público, didática e cientificamente, o conceito marxista de mais-valia. Para dar consistência ao espetáculo, houve a colaboração do sociólogo Carlos Estevam, então assistente de Álvaro Vieira Pinto no ISEB. Com o fim das apresentações na Faculdade de Arquitetura da Universidade do Brasil, conjugando interesses de artistas e estudantes, foram abertas as discussões sobre uma colaboração ampla para a consolidação de uma ação cultural popular e revolucionária. O grupo dissidente do Teatro de Arena se aproxima, então, da União Nacional dos Estudantes em busca de apoio institucional. Obtém a cooperação da gestão da UNE, que estava a cargo de Aldo Arantes, militante que possuía ligações com a esquerda católica que logo formaria o movimento Ação Popular (AP).

A partir da efervescência surgida com a montagem de $A$ mais valia vai acabar, seu Edgar, e com a associação de interesses de sujeitos ligados ao ISEB, UNE e PCB, nasce no Rio de Janeiro, em dezembro de 1961, o primeiro Centro Popular de Cultura (CPC). Os nomes que formaram o núcleo inicial das atividades variam conforme os relatos dos envolvidos e a produção historiográfica. No entanto, são recorrentes as figuras de Vianinha, Carlos Estevam, Leon Hirszman, Carlos Lyra e Chico de Assis. A eles, depois se juntaram Ferreira Gullar, Cacá Diegues, Eduardo Coutinho e Carlos Vereza. 


\section{ARTE POPULAR REVOLUCIONÁRIA}

Em meio ao clima de discussões sobre a Reformas de Base do governo do presidente João Goulart, o CPC da UNE foi visto por seus membros como uma "vanguarda cultural das massas trabalhadoras" (RIDENTI, 2014, p. 79). Houve uma intensa produção político-artística que extrapolou a área do teatro e incluiu, também, música, cinema e literatura. Para além da criação intelectual, os cepecistas protagonizaram uma crescente mobilização militante. Em 1962, a União Nacional dos Estudantes, a partir de sua sede no Rio de Janeiro, criou um grupo itinerante que viajava por diversas cidades brasileiras. O seu objetivo era discutir as pautas estudantis, mas, fundamentalmente, a reforma universitária. A chamada UNE-Volante era formada também pelo CPC que, através de várias atividades, como a encenação de peças, ajudava a refletir sobre temas de interesse do movimento estudantil. Essa mobilização permitiu a criação de mais centros populares de cultura, formando uma verdadeira rede de produção artística participante. Com isso, surgiram, além dos sete em funcionamento na capital carioca, outros doze CPCs, em diferentes cidades e estados. A ênfase em uma ou outra área cultural e os modos específicos de atuação variavam de acordo com o lugar e os envolvidos.

Desse modo, a rigor, quando aqui falamos do CPC no singular, nos referimos à sua sede no Rio de Janeiro. Do ponto de vista dos jogos de composição institucional, havia momentos de conflito entre UNE e CPC. Os dirigentes dos dois órgãos provinham, em sua maior parte, da Ação Popular ou do Partido Comunista Brasileiro, que tinham divergências ideológicas. O "Centro Popular de Cultura era basicamente o PC que trabalhava, enquanto que na diretoria da UNE estava a AP" (BARCELLOS, 1994, p. 213). O que também não excluía tensões entre o PCB e cepecistas. Administrativamente, o órgão teve formatos variados. No entanto, manteve invariavelmente, além da presidência, um conselho diretor composto por representantes dos diferentes setores - do teatro ao cinema. Havia, ainda, uma área encarregada da distribuição de livros e discos produzidos pelo CPC: o Programa de Divulgação e Assistência Cultural (PRODAC). Essa organização não impedia que as práticas, para além de qualquer dirigismo, fossem ambíguas. O que mostra que havia uma grande diversidade prático-ideológica no interior do órgão.

Normalmente discutido como mero efeito do Anteprojeto do Manifesto do Centro Popular de Cultura, de março de 1962, escrito por Carlos Estevam, a história do CPC da UNE ultrapassa a redução a esse texto que, afinal, foi redigido para uso interno. Estevam e Ferreira Gullar foram ideólogos influentes no interior da entidade ao suturarem as noções de cultura popular e revolução. No campo da criação, Vianinha se destacava na "arregimentação, divulgação, contatos, elaboração de textos, ensaios, representação, e, até mesmo, impressão de folhetos" (BETTI, 1997, p. 112). No entanto, eles não eram as únicas vozes. Essas lideranças - já por si mesmas diversas - não significavam ausência de confrontos. Apenas depois de intensas disputas houve a hegemonização das diretrizes do manifesto.

Com efeito, o Anteprojeto do Manifesto apontava para duas únicas opções para os artistas: ou atuar revolucionariamente na vida concreta dos homens ou tornar-se idealista e matéria passiva. A inocuidade 
artística decorreria da incompreensão do "contexto social determinado por leis objetivas". No texto, há a perspectiva de que "qualquer manifestação cultural só pode ser adequadamente compreendida quando colocada sob a luz de suas relações com a base material sobre a qual se erigem os processos culturais de superestrutura" (ESTEVAM, 1981, p. 122-123). Do que se depreende uma argumentação marxistaracionalista, que indicava a existência de uma verdade única centrada na esfera econômica.

Segundo Carlos Estevam, o artista de esquerda deveria ser um revolucionário que optou "por ser povo, por ser parte integrante do povo, destacamentos de seu exército no front cultural.” Proposta, então, de uma vanguarda revolucionária orientada por um dirigismo, paternalismo e voluntarismo. Do ponto de vista desse modelo, o artista deveria construir suas obras não como arte do povo (ingênua), tampouco como arte popular (arte para as massas), mas no campo estrito da arte popular revolucionária. Assim, "fora da arte política não há arte popular" (ESTEVAM, 1981, p. 128-140).

Dessa maneira, pode-se falar de uma estética do conteúdo revolucionário e da instrumentalização da arte para a transformação social. As formas simbólicas populares deveriam ser reelaboradas para propagar ideias revolucionárias. A ênfase recairia na mensagem para se chegar, finalmente, “à consciência do outro e dum outro que" é "exatamente o povo." Segundo essa perspectiva, "a qualidade do artista brasileiro [...] é a de tomar consciência da necessidade e da urgência da revolução brasileira" (ESTEVAM, 1981, p. 127-143). Ele "deveria se converter aos novos procedimentos, nem que, para isso, sacrificasse o seu deleite estético e a sua vontade de expressão pessoal, em nome de uma pedagogia política que atingisse as massas." Não deveria haver "sofisticação", mas "comunicação" conscientizadora do povo em detrimento da "expressão" (NAPOLITANO, 2001, p. 38).

Essas ideias estavam melhor amparadas no chamado "agitprop", arte de agitação e propaganda, levado a cabo pelos cepecistas nas ruas, sindicatos e favelas. No campo da dramaturgia, emergia um teatro de choque, que interpelava o "povo" em nome da reforma agrária, da luta contra o imperialismo, etc. As reações a essas ideias não foram de simples aceitação. Vianinha, em um primeiro momento, aderiu às diretrizes para em seguida revê-las. Entretanto, o embate que obteve maior repercussão deixando inclusive marcas nas memórias dos antagonistas - envolveu Carlos Estevam e os cineastas que integravam o CPC da UNE e que iniciavam o processo de gestação das ideias do que viria a ser o Cinema Novo.

A compreensão das disputas sobre o significado da arte voltada para a cultura popular revolucionária não deve, desse modo, elidir o fato de que alguns dos diretores, além de cinemanovistas, foram simultaneamente cepecistas. ${ }^{1} \mathrm{O}$ diretor Cacá Diegues, por exemplo, que participou ativamente do $\mathrm{CPC}$, reconhece que para ele e muitos outros A mais valia vai acabar, sen Edgar foi, "durante muito tempo, modelo de uma possível arte popular brasileira politizada” (DIEGUES, 2014, p. 119). Havia também no

\footnotetext{
${ }^{1}$ São citados como participantes da entidade: Carlos Diegues, Arnaldo Jabor e Leon Hirszman. Glauber Rocha fez parte do CPC da Bahia. Essa íntima colaboração pode ser constatada na produção e divulgação do único filme finalizado pelo CPC. Cinco Vezes Favela (1962) é formado por cinco curtas-metragens dos diretores cinemanovistas. O episódio intitulado Escola de Samba Alegria de Viver, por exemplo, foi dirigido por Cacá Diegues, mas o roteiro foi escrito por seu futuro desafeto, o ideólogo Carlos Estevam.
} 
"Cinema Novo uma preocupação marcante" com "a utilização de elementos da cultura popular como ponte para atingir o povo: a ideia é que se faça um cinema popular (que se dirija ao povo) com matériaprima popular (que vem do povo)" (BERNARDET; GALVÃO, 1983, p. 139). Portanto, era necessário partir da constatação da existência de conflitos que expressavam a luta pela hegemonia de pensamento no órgão de cultura da UNE.

Segundo o ponto de vista de Cacá Diegues, o "CPC nos fazia refletir sobre as possibilidades de uma cultura nacional e escolhia sua face popular, nos expondo a um corpo a corpo com a população, com a qual acabávamos por aprender mais do que ensinar" (DIEGUES, 2014, p. 122). Essa compreensão de pertencimento o levou a afirmar: "nós também éramos CPC" (BARCELLOS, 1994, p. 43). Arnaldo Jabor, por sua vez, compreendia que o Cinema Novo seria a síntese crítica do Arena e do CPC. Glauber Rocha, em um momento de proximidade com o movimento cepecista, chegou a afirmar: "O CPC é o mais importante movimento da juventude brasileira de hoje; é uma posição de levar cultura politizante às massas através da poesia, do teatro, da música e do cinema" (ROCHA, 2003, p. 139). Assim, "uma das bases que moldou a grandeza do Cinema Novo foi o CPC" (DOMONT, 1997, p. 100101).

A discussão interna sobre o significado da arte popular revolucionária se tornou cada vez mais acirrado entre Estevam e cinemanovistas. Em 1962, as divergências tomaram feições de debate público e ganhou as páginas do jornal estudantil O Metropolitano. O embate envolveu desacordos com as premissas do Anteprojeto do Manifesto. Os "cineastas que se dispunham a participar dos movimentos de cultura popular não estavam igualmente dispostos a autocercear sua liberdade criadora." Para eles, "a possibilidade de livre criação era precisamente um dos pontos de incentivo à atividade artística." Contra esse tipo de posicionamento, Estevam lançava acusações contra os cinemanovistas: "Os rapazes (do Cinema Novo) estão enlatados na encruzilhada de duas contradições: 1) a defesa de um cinema social hermético, ou 2) a defesa, feita por revolucionários, mas em nome da cinematografia, do cinema antirevolucionário." O que selou o afastamento, nesse mesmo ano, "da maior parte dos representantes do Cinema Novo do grupo do CPC” (BERNARDET; GALVÃO, 1983, p. 147-157).

Glauber Rocha irá recordar o momento de ruptura da seguinte maneira: "nos recusamos a participar da visão cultural paternalista em moda e preferimos fazer um cinema político que não tivesse a ingenuidade demagógica de se justificar como 'principal instrumento revolucionário"' (ROCHA, 1997, p. 400-401). Com efeito, o ponto de maior impasse na diatribe estava por conta da escolha dos diretores por uma experimentação da linguagem cinematográfica. As formas, para os cinemanovistas, estavam investidas de caráter político. As visualidades estabelecidas não eram isentas de significados ideológicos que deveriam ser criticados. Assim, as contradições da moderna cultura artística brasileira se adensavam nos anos 1960 a partir da intelectualidade jovem de esquerda. Surgiram oposições entre forma e conteúdo, arte útil e inútil, esquerda e direita, autonomia artística e engajamento, militância e alienação. Entretanto, a hegemonia do pensamento ligado a Carlos Estevam não encontrou resistência apenas entre 
os cinemanovistas. O afastamento deles não deu por resolvida a contradição forma/conteúdo revolucionário. O problema acompanharia a trajetória do CPC da UNE até o seu fim.

A crítica de alguns dos postulados do Anteprojeto do Manifesto conduziu os membros do CPC, entre 1963 e 1964, a repensar progressivamente a priorização da mensagem política em detrimento da elaboração artística. Nesse momento, a liderança de Estevam "é abertamente questionada sob o ponto de vista de sua representatividade em relação ao Centro Popular de Cultura como um todo" (BETTI, 1997, p. 132). Ferreira Gullar assumiu, então, a presidência da entidade para mediar os conflitos. Os textos que escreveu no seu período de militância o tornaram um dos intelectuais mais relevantes para a entidade. Não é incomum ver seus ensaios arrolados como sendo menos dogmáticos do que os de Estevam.

A compreensão de Gullar dos pressupostos de atuação do CPC da UNE está presente no livro Cultura Posta em Questão, escrito em 1963. O poeta permanece, nesse ensaio, no âmbito das preocupações cepecistas: instrumentalizar a arte na defesa de uma cultura popular, nacional, anti-imperialista, desalienada e revolucionária. A obra de arte deveria ser vista como "ação sobre a realidade" que busca justiça social e econômica. O "criador no campo da cultura popular" teria como objetivo trabalhar "para" e "com" as massas proletarizadas (GULLAR, 2010, p. 17-26). É justamente Gullar o principal nome da literatura cepecista. É na sua escrita e dos seus colegas de movimento que buscaremos deslindar a seguir o problema da imaginação temporal na literatura do CPC da UNE.

\section{CPC E ROMANTISMO REVOLUCIONÁRIO}

O exame da relação entre escrita e temporalidade na literatura cepecista pode partir da tese desenvolvida por Marcelo Ridenti sobre as esquerdas brasileiras dos anos 1960 e início dos 1970. Ele afirma que é possível falar de um romantismo revolucionário "para compreender as lutas políticas e culturais" desse momento histórico: desde o "combate da esquerda armada" até as "manifestações políticos-cultuais na música popular, no cinema, no teatro, nas artes plásticas e na literatura" (RIDENTI, 2014, p. 08). Se, conforme observa, a caracterização de parte da esquerda em relação às suas próprias práticas como românticas era frequente, isso teria um significado que vai além da mera alusão à ingenuidade. O conceito de romantismo utilizado por Ridenti para elaborar sua tese foi colhido nas discussões de Michael Löwy e Robert Sayre sobre o tema.

Para esses autores, o romantismo, na condição de visão de mundo surgida na Europa a partir do século XVIII, é uma crítica cultural dirigida ao capitalismo. O romantismo é uma "autocrítica" da modernidade. Modernidade e romantismo, enquanto processos históricos inseparáveis, se prolongam no tempo, nos sendo, por isso mesmo, contemporâneos. Nesse sentido, podemos falar dos seus aspectos intrinsicamente inacabados. A sensibilidade melancólica e nostálgica romântica está ligada à experiência de perda do passado e da comunidade (símbolo maior da totalidade) desencadeada pela chegada da modernidade. Assim, com a modernização, teríamos mecanização, quantificação, objetivação, 
racionalização do mundo e a dissolução dos vínculos sociais orgânicos. A esse processo é contraposto a qualidade, a união mítica comunal, o povo orgânico, laços íntegros de solidariedade, entre outros (LÖWY; SAYRE, 2015, p. 52-82).

O romantismo é marcado por uma ambiguidade constitutiva:

O romantismo é igualmente jovem e decadente, exótico e corriqueiro, dinâmico e tranquilo, afirmando a vida mas amando a morte, individualista e comunitário, apaixonado pelo concreto mas envolto em imprecisão espiritual, primitivo e afetado, simples e sofisticado, inspirado pelo passado mas entusiasmado com a originalidade, dedicado à unidade mas rejubilando na diversidade, comprometido com a arte como um fim em si mesmo e ainda assim servindo de instrumento para a regeneração social (EAGLETON, 2016, p. 104).

A visão romântica, vista a partir da política, possui igualmente uma diversidade de perspectivas - todas ligadas à saudade infinita da tradição - que foi tipificada por Michael Löwy e Robert Sayre da seguinte maneira: restitucionista, conservadora, fascista, resignada, reformadora, revolucionária e/ou utópica. Nesta última acepção podemos divisar os matizes jacobino-democrático, populista, socialista utópico-humanista, libertário e marxista (LÖWY; SAYRE, 2015, p. 85-117).

Desse modo, Ridenti vislumbra manifestações românticas nas esquerdas brasileiras como sendo predominantemente do tipo revolucionárias, comportando variações e intensidades:

\begin{abstract}
A utopia revolucionária romântica do período valoriza acima de tudo a vontade de transformação, a ação dos seres humanos para mudar a História, num processo de construção do homem novo, nos termos do jovem Marx, recuperados por Che Guevara. Mas o modelo para esse homem novo estava no passado, na idealização de um autêntico homem do povo, com raízes rurais, do interior, do "coração do Brasill", supostamente não contaminado pela modernidade urbana capitalista. [...] $\mathrm{O}$ romantismo das esquerdas não era uma simples volta ao passado, mas também modernizador. Ele busca no passado elementos para a construção da utopia do futuro. Não era, pois, um romantismo no sentido da perspectiva anticapitalista prisioneira do passado, geradora de uma utopia irrealizável na prática. Tratava-se de romantismo, sim, mas revolucionário. De fato, visava-se retomar um encantamento da vida, uma comunidade inspirada no homem do povo, cuja essência estaria no espírito do camponês e do imigrante favelado a trabalhar nas cidades (RIDENTI, 2014, p. 9).
\end{abstract}

A abrangência da hipótese do romantismo revolucionário é, em todo caso, problemática. A miríade de objetos e sujeitos arrolados por Ridenti possuem, cada qual, suas singularidades que merecem abordagem histórica específica. Contudo, entendemos que os cepecistas, de fato, capturavam em produções artísticas a visão romântico-revolucionária.

O romantismo revolucionário cepecista conjugava elementos antimodernos e revolucionários em obras. Essa combinação tem como efeito a construção de uma imaginação temporal feita do choque entre um fragmento do passado encontrado no presente e voltado para o futuro. Como assinalamos, a "razão dualista" e a ideia do PCB de que a revolução seria efeito do progresso - com etapas a serem cumpridas na consecução de um socialismo no Brasil - não foram simplesmente reproduzidas. Na produção cultural cepecista isso fica bastante claro na tentativa de "salvar" algo que existe no presente, mas vindo do passado, e que orientaria a coletividade em direção à concretização da utopia. Um arranjo 
temporal, em âmbito estético, onde espaço de experiência e horizonte de expectativa se combinam desequilibradamente (KOSELLECK, 2006, p. 305-327). Segundo essa visada, nem todos os valores rurais e anticapitalistas deveriam ser desconsiderados ou destruídos na construção da nova sociedade brasileira.

No entanto, essa construção temporal não era imune a problemas. Com relação à noção de povo, Ridenti cita a crítica de Sérgio Paulo Rouanet ao CPC da UNE. Para o filósofo brasileiro, existiria proximidade entre romantismo revolucionário cepecista e conservador alemão:

\begin{abstract}
O povo, nos anos 1960, era visto seja como massa inerte, inculta, despolitizada [...] cuja consciência política precisava ser desperta por sua vanguarda, estudantes e intelectuais urbanos; seja como um povo já de posse de si mesmo, portador de uma sabedoria espontânea, sujeito a fundamento da ação política. Havia um povo que ainda não é, e deve ser objeto de uma pedagogia, e um povo que já é, e deve ser o objeto de uma escrita, porque a sua é a voz da história [...] O "povo" dos anos 1960 tinha muitas vezes uma semelhança inconfortável com o volk do romantismo alemão [...]: a nação como individualidade única, representada pelo povo, como singularidade irredutível (RIDENTI, 2014, p. 15).
\end{abstract}

Essas asseverações mostram que a tentativa de ir ao passado em busca da força política para resistir ao capitalismo pode desencadear posições reativas. Essa reação não é distante dos aspectos autoritários que a visão romântico-nacionalista pode assumir. Não sendo apanágio exclusivo dos tipos mais conservadores, eles podem ser encontrados na cultura política do CPC, nos anos 1960.

Nesse sentido, é a idealização da autêntica cultura do povo que coloca parte das obras e atividades cepecistas sob o risco de servir-se de um dirigismo. A pedagogia revolucionária levava-os a "pensar que o favelado é um ser ingênuo; que ali está como um índio, um ser primitivo; que não sabe de nada e que você vai plantar a cultura para ele, a consciência" (DOMONT, 1997, p. 86). A esse respeito, Renato Ortiz aponta que a noção de cultura popular cepecista rompia com aquela erigida pelos intelectuais brasileiros tradicionais e antimodernos. Isso ocorria na medida em que "o termo [cultura popular] se reveste, portanto, de uma outra conotação, significa sobretudo função política dirigida em relação ao povo" (ORTIZ, 2012, p. 72).

Não obstante, ele ressalva que as lutas contra a alienação, a inautenticidade da cultura de massa e o imperialismo norte-americano acarretavam um nacionalismo que torna mais nuançado esse rompimento. A invasão do capital estrangeiro através da indústria cultural - a exemplo do consumo do rock em detrimento da música folclórica regional - gerava a compreensão cepecista de que existiria uma identidade brasileira violada ou em vias de se perder na exploração capitalista. Em resumo: "Uma vez que a noção de alienação se confunde com a de inautenticidade, pode-se estabelecer uma aproximação entre concepções que a priori se apresentavam como frontalmente antagônicas” (ORTIZ, 2012, p. 76105).

Os enfrentamentos contra a massificação, quantitativismo e tecnicismo em nome de valores humanos, levado a cabo pelo pensamento tradicional brasileiro, não são totalmente estranhos a certos posicionamentos, obras e práticas cepecistas. Com isso, os estilemas antimodernos convivem com os 
modernos de maneira irresolvível na ideologia cultural do CPC. Uma coexistência de caráter "oximoresco", espécie de saudade progressista. Temos aqui uma combinação de marxismo racionalista ortodoxo com idealização romântica do povo-nação "como guardião da comunidade e das atividades vitais do homem brasileiro" (RIDENTI, 2014, p. 16). Essa composição estético-política fica patente na temporalidade presente na produção literária realizada no âmbito do CPC.

\section{VIOLÃO DE RUA: REPRESENTAÇÃO LITERÁRIA DO POVO BRASILEIRO}

A produção literária cepecista começa com os poemas de Ferreira Gullar. A cena inicial consta como um pedido. Vianinha solicitou ao literato "um poema, estilo cantador de feira, que iria servir como uma espécie de roteiro, de espinha dorsal da peça" que ele planejava sobre a reforma agrária (BARCELLOS, 1994, p. 210). O projeto da peça não se realizou, mas João Boa-morte, cabra marcado para morrer foi escrito e publicado em 1962, com grande tiragem, inaugurando as atividades editoriais da entidade. ${ }^{2} \mathrm{O}$ livro "foi vendido em vários estados. Na GB [Guanabara], grupos do CPC venderam na porta da Central do Brasil, lendo trechos dos poemas para um grande número de pessoas, na sua maioria operários" (BARCELLOS, 1994, p. 450).

João Boa-morte conta a história de Pedro João Boa-Morte, um tipo nordestino explorado pelo rico coronel Benedito. A família do camponês é composta por "seis crianças com os olhos cavados de fome" e sua mulher, Maria, "que a tristeza na luta de todo dia tão depressa envelheceu". João frequentemente se perguntava sobre as injustiças que pesavam sobre os pobres trabalhadores. Enquanto isso, os camponeses mostravam seus nobres valores, que se contrapunham à exploração do latifundiário. João, revoltado com o assassinato de um dos seus amigos pelo coronel, procurou reunir os lavradores para livrar o "sertão do jugo do fazendeiro". O dono da fazenda, ao saber da movimentação sediciosa, expulsa o camponês e sua família, difamando-o como comunista por toda a região para que não encontrasse mais trabalho (GULLAR, 2008, p.104-113).

João, errando pelo mundo sem ajuda, acaba perdendo um dos seus filhos. Sem esperanças, decide matar toda a família e cometer suicídio para fugir daquela dramática situação. No entanto, antes que cometesse o ato desesperado, é interrompido por Chico Vaqueiro. O lavrador exorta-o a seguir o "caminho verdadeiro" da luta nas Ligas Camponeses. Assim, João e sua família são salvos pelo chamado revolucionário:

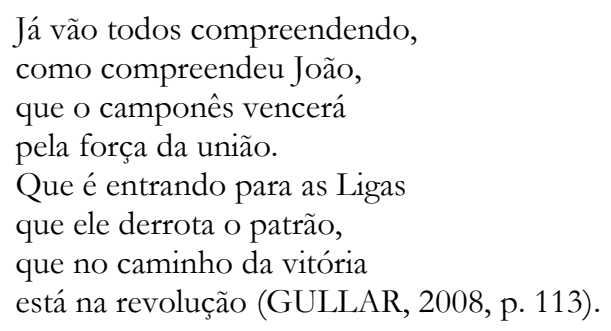

2 A primeira edição de julho de 1962 teve 5 mil exemplares editados e a segunda, em novembro do mesmo ano, 10 mil. 
Assim, a revolução futura tem origem nos valores arcaicos de solidariedade heroica do homem do mundo rural. A utilização consciente dos "conhecimentos literários" como instrumento político não deixa de produzir ressonâncias “anacrônicas" (GULLAR, 2002, p. 157). Desse modo, a ideia cepecista de forma e conteúdo divorciadas não se aplica sem problemas. O uso de formas "tradicionais" como meio de transmissão acessível de mensagens ideológicas pode ser visto como confronto de tempos contrários: tempo futuro das transformações sociais engastado na forma "passada" do cordel.

João Boa-morte e os outros cordéis de Gullar são paradigmáticos da literatura produzida em meio aos debates sobre cultura popular no CPC. ${ }^{3}$ Os mesmos problemas são encontrados nos livros de poemas publicados pela entidade e pela editora Civilização Brasileiro, de Ênio da Silveira, que compõem a conhecida coletânea Violão de Rua: Poemas para a Liberdade. A série, iniciada em 1962 e interrompida pelo golpe de 1964, teve três publicações em formato de bolso dentro da coleção Cadernos do povo brasileiro. Nessas poesias, transparecem "a emoção dos poetas pelo sofrimento do próximo, a denúncia das condições de vida sub-humanas das grandes cidades, e, sobretudo, no campo". A maioria "expressava a recusa da ordem social instituída por latifúndios, imperialistas e - no limite, em alguns textos - pelo capitalismo" (RIDENTI, 2014, p. 95).

A atmosfera encontrada nessa literatura era de "experiência de perda da humanidade, certa nostalgia melancólica de uma comunidade mítica já não existente e a busca do que estava perdido, por intermédio da revolução brasileira" (RIDENTI, 2014, p. 96). As figuras populares - camponeses, operários, retirantes e pobres - são vistas como portadores de valores comunitários que se contrapõem à exploração. $\mathrm{O}$ organizador dos livros foi o poeta e jornalista Moacyr Félix que, para essa tarefa, se associou ao CPC. Nas introduções escritas para as coletâneas ele defendeu o humanismo e a solidariedade como móveis da "revolução do homem brasileiro." Violão de Rua estimularia a "busca de uma linguagem que não se distancia dos ritmos populares", não descartando, entretanto, outros estilos literários que também expressassem "sentimentos de inconformidade ou suas exigências de um mundo mais livre” (FÉLIX, 1962b, p. 9-10).

Essa abertura, por outro lado, longe de ser absoluta, não excluía a tentativa de dar um "solavanco nas torres de marfim de uma estética puramente formal, conservadora e reacionária" que "resvala sempre para o sentido do divertissement e do ornamental", em clara alusão às vanguardas concretistas, neoconcretistas e praxistas que tinham destaque no campo artístico desde a década de 1950. Os verdadeiros poetas seriam os "homens da negação" intimamente ligados ao "projeto de desalienação existente na história". Eles recusariam os determinismos sociais em nome da liberdade (FÉLIX, 1963, p. 9-11).

Essas escritas - mas, também outras produções estéticas das esquerdas - constroem imagens do povo como vítima "pura, virtuosa e, mais ainda, espiritualizada e, por oposição, o algoz como vicioso" (CAMARÁ, 2014, p. 46). O corpo do trabalhador é sofredor e sem qualquer materialidade, ludicidade

\footnotetext{
${ }^{3}$ Gullar escreveu, nesse período, Quem Matou Aparecida, Peleja de Zé Molesta com o Tio Sam e História de um Valente.
} 
ou erotismo - o que, de resto, já estava presente em João Boa-morte. No poema Ministrinho, ministrãa, de Moacyr Félix, podemos ler "a livre falação que o cantador achou nas ruas para os membros do Gabinete que governa essa nação":

$$
\begin{aligned}
& \text { Com seu tempo desgraçado } \\
& \text { de só poder se alugar, } \\
& \text { o povo vai para a praça } \\
& \text { com seu pouco de comprar. } \\
& \text { E os cadilaques passando, } \\
& \text { Com gente de só gozar; } \\
& \text { E as buates estufando } \\
& \text { como um gordo a se engordar } \\
& \text { sobre esta coisa vazia } \\
& \text { onde cresce o chá-chá-chá } \\
& \text { Ministrinho, ministrão } \\
& \text { Olha pro céu, e olha pro chão. } \\
& \text { Proletário ou camponês, } \\
& \text { O tempo de quem trabalha } \\
& \text { Nunca é sim, sempre é talvez; } \\
& \text { não é vida, e sim mortalha } \\
& \text { costurada mês a mês. } \\
& \text { (FÉLIX, 1962a, p. 56) }
\end{aligned}
$$

Há nesse poema a oposição entre corpo do povo, pensado apenas pelo crivo do mundo do trabalho, e corpo das classes dominantes, vinculado ao prazer. "As imagens que eram produzidas pela arte engajada", fundamentalmente a cepecista, "não reivindicavam um corpo gozoso" e sua "sintaxe revolucionária possuía uma semântica sofredora, pura e casta” (CAMARÁ, 2014, p. 47).

No poema Come e Dorme, de Félix de Athayde, essa oposição fica por conta da figuração do pobre que apenas "lavra a terra", "brita a pedra", "amassa o pão" enquanto o rico "faz a guerra", "come e dorme" (FÉLIX, 1962b, p. 36-37). No poema Vivência, de Paulo Mendes Campos, encontramos contrastados o valor do trabalho proletário e o corpo erótico improdutivo. No texto lemos a condenação da prostituição e a preferência por "encontrar um coração veemente / de companheiro [...] /apertar a mão amiga e dura / Dum operário / Mão-martelo que prega a investidura / Do proletário" (FÉLIX, 1963, p. 121).

São imagens do povo ideais, heroicas, unificadoras e abstratas que evitam ambiguidades. Esse povo casto, dedicado ao labor, ingênuo, "tão pobre quanto bom", "paciente por dom" e que "trabalha para comer" parece romanticamente saído de um imaginado mundo antimoderno (GULLAR, 2008, p. 115-125). Os resultados dessa representação implicam uma imagem temporal distinta da seta futurista revolucionária da "razão dualista" tal como pensada pelo PCB. Nos poemas da coleção Violão de Rua o passado é "recuperado" como possuindo, em alguma medida, uma força contestadora no presente. Assim, a literatura cepecista, com conteúdo revolucionário, mostra toda a implicação temporal entre passado e futuro relativa ao romantismo revolucionário.

Violão de Rua "expressou a utopia do povo como regenerador e redentor da humanidade, mesclado a um marxismo humanista." Nessa série de poemas "a utopia marxista confundia-se com a utopia romântica da afirmação da identidade nacional do povo brasileiro com raízes pré-capitalistas" 
(RIDENTI, 2014, p. 101). Esse imaginário temporal evitava "outras visões possíveis do povo, condenando-o a uma martirização que extirpava qualquer política estética que tivesse surgido de um 'uso alegre' dos corpos" (CAMARÁ, 2014, p. 47). Nessa perspectiva, era apresentada a tarefa do artista participante: "o poeta deve ser o primeiro a saber e o último a esquecer que na singularidade de cada homem injustiçado é toda a humanidade que sofre" (FÉLIX, 1963, p. 12).

\section{CONSIDERAÇÕES FINAIS}

O sonhado contato com as classes trabalhadoras em favelas e sindicatos não estabeleceu os resultados esperados pelos cepecistas. A aliança ideológica com o "povo" não aconteceu, sendo arregimentadoa apenas jovens intelectuais de classe média. Os integrantes do CPC, sob forma de balanço de suas trajetórias, acreditam que a visão paternalista impediu a aliança entre vanguarda revolucionária e "povo". Além disso, os cepecistas teriam ignorado a ampla rede política conservadora hegemônica que atravessava os extratos sociais populares (DOMONT, 1997, p. 86-87). Diante desse impasse, foi discutida a possibilidade de modificar a estratégia ideológica utilizada até aquele momento. Entretanto, o CPC chegou ao fim antes que essa reorientação programática ocorresse.

A razão fundamental para o encerramento das atividades cepecistas foi o golpe civil-militar de 1964. No dia 1 abril, a sede do CPC da UNE no Rio de Janeiro amanheceu destruída por um incêndio e rajadas de metralhadora - a violência perpetrada pelas forças autoritárias estava apenas começando. $\mathrm{O}$ que explica a curta duração da experiência estética e política cepecista. Aniquilado como foi, o CPC da UNE ressurgiria apenas como "mito" nas memórias de seus integrantes. Alguns ex-cepecistas, diante do encurtamento das possibilidades de atuação política em meio à opressão do Estado autoritário, buscaram manter a tática da aliança de classes nacional, popular e revolucionária por meio da constituição do Grupo Opinião. Formado por Ferreira Gullar, Oduvaldo Vianna Filho, Teresa Aragão, Paulo Pontes, João das Neves, entre outros, o grupo optou pela retomada de problemáticas ignoradas anteriormente. Assim, a recuperação da dialética forma e conteúdo, das técnicas expressivas e dos debates estéticos tinham como objetivo a montagem de espetáculos teatrais elaborados e politicamente engajados. O resultado foi o Show Opinião realizado ainda em 1964. Entretanto, a alternativa sofreu com o AI-5 de 1968 e o recrudescimento do regime militar. Ao mesmo tempo, emergiram críticas oriundas do campo da esquerda. Parte da esquerda acreditava que o Grupo Opinião manteve as "representações romantizadas" cepecistas que celebravam o "povo engajado na luta revolucionária" (DUNN, 2009, p. 73-76).

Com efeito, o sentimento de malogro da suposta atmosfera revolucionária atravessou a autocompreensão dos cepecistas no pós-golpe. As tentativas de abordagem do CPC da UNE encontram avaliações negativas que criaram extratos de memória que nasceram logo após o Golpe de 1964 quando o programa de aliança de classes foi sendo recusado. Diante disso, surgem dissidências no seio das esquerdas, por exemplo em torno da validade da luta armada. Na outra margem, a da moderna cultura artística, o movimento tropicalista, nascido no fim dos anos 1960, tinha como proposta a arte engajada. 
As ideias contraculturais se disseminaram gerando, em muitos casos, a ruptura com os intelectuais participantes. Assim, o "nacional-popular cepecista" tornou-se "símbolo de uma ação cultural autoritária, mistificadora". Até mesmo as atividades dos seus integrantes no pós-golpe passaram a ser vistas como "afeita às regras do mercado" e seu nacionalismo como passível de dissolver-se nos ideais ufanistas do regime ditatorial (NAPOLITANO, 2017, p. 282).

Segundo Maia Silvia Betti (1997, p. 82-86), a produção acadêmica em torno do CPC da UNE toma fôlego a partir de 1978. Os trabalhos pioneiros revelavam grande proximidade pessoal com o objeto de estudo. Já na década de oitenta, parcela mais ampla das pesquisas foi demandada por universidades, órgãos culturais oficiais e mercado editorial. Parte desses estudos reduziram suas análises apenas à apreciação do Anteprojeto do Manifesto, de Carlos Estevam. O que gerou certa leitura homogeneizadora - a exemplo da abordagem de Marilena Chaú (1983, p. 86-92). Somam-se a essa camada interpretativa as obras que tomam caráter de apresentação panorâmica.

As perspectivas críticas sobre a cultura ideológica e artística cepecista devem, portanto, enfrentar essas camadas de memória e intepretação. Um desses enfrentamentos, como mostramos, pode partir justamente da discussão sobre a temporalidade cepecista. A abordagem dos tempos agenciados pela produção literária é uma das muitas maneiras de repensar o CPC da UNE para além dos reducionismos programáticos. Nesse sentido, a ideologia do progresso, pensada como universal por parte das esquerdas brasileiras, foi reelaborada pela poética cepecista sob a forma de uma combinação de nostalgia e utopia. A visão "romantizada" do povo como guardião da essência nacional e do desejo de justiça social gerava uma fatura artística duplamente problemática: reduzia a arte a um instrumento político e construía uma idealização do povo-nação. Por fim, acreditamos que essa mesma visada sobre a imaginação temporal da poesia cepecista pode ser deslocada e adaptada para pensar historicamente outras produções artísticas do CPC da UNE, no cinema, teatro e música.

\section{REFERÊNCIAS}

BARCELLOS, J. CPC da UNE: uma história de paixão e consciência. Rio de Janeiro: Nova Fronteira, 1994.

BERNARDET, J.-C.; GALVÃO, M. R. Cinema: repercussões em caixa de eco ideológica. Nacional e popular na cultura brasileira. São Paulo: Embrafilme; Brasiliense, 1983.

BETTI, M. S. Uduvaldo Vianna Filho. São Paulo: Ed. da USP, 1997.

CAMARÁ, M. Corpos pagãos: usos e figurações do corpo na cultura brasileira. (1960-1980). Belo Horizonte: Ed. da UFMG, 2014.

CHAUÍ, M. Seminários. O nacional e o popular na cultura brasileira. São Paulo: Brasiliense: 1983.

DIEGUES, C. Vida de cinema. Antes, durante e depois do cinema novo. Rio de Janeiro: Record: 2014. 
DOMONT, B. Um sonho interrompido: o Centro Popular de Cultura da UNE. 1961-1964. São Paulo: Porto Calendário, 1997.

DUNN, C. Brutalidade Jardim: a tropicália e o surgimento da contracultura brasileira. São Paulo: Ed. da UNESP, 2009.

EAGLETON, T. A Morte de Deus na Cultura. São Paulo: Record, 2016.

ESTEVAM, C. Anteprojeto do Manifesto do Centro de Cultura Popular, Redigido em março de 1962. In: HOLANDA, H. B. de. Impressões de viagem: CPC, vanguarda e desbunde (1960-70). São Paulo: Brasiliense, 1981. p. 121-144.

FÉLIX, M. (org.). Violão de rua: poemas para liberdade. Rio de Janeiro: Civilização Brasileira, 1962a. (Col. Cadernos do Povo Brasileiro, v. I).

FÉLIX, M.. (org.). Violão de rua:. Rio de Janeiro: Civilização Brasileira, 1962b. (Col. Cadernos do Povo Brasileiro, v. II).

FÉLIX, M.. (org.). Violão de rua:. Rio de Janeiro: Civilização Brasileira, 1962c. (Col. Cadernos do Povo Brasileiro, v. III).

GARCIA, M. Do teatro militante à música engajada: A experiência do CPC da UNE (1958-1964). São Paulo: Perseu Abramo, 2007.

GULLAR, F. Cultura posta em questão: vanguarda e subdesenvolvimento. Rio de Janeiro: José Olympio, 2010.

GULLAR, F. Ferreira Gullar conversa com Ariel Jiménez: São Paulo: Cosac \& Naify, 2002.

GULLAR, F. João Boa-morte, cabra marcado para morrer. Quem matou Aparecida. História de uma favelada que ateou fogo às vestes. In: GULLAR, F. Poesia completa, Teatro e Prosa. Rio de Janeiro: Nova Aguilar, 2008.

KOSELLECK, R. Futuro passado: Contribuição à semântica dos Tempos Históricos Rio de Janeiro: Contraponto; PUC-Rio, 2006.

LÖWY, M; SAYRE, R. Revolta e melancolia: o romantismo na contracorrente da modernidade. São Paulo: Boitempo, 2015.

NAPOLITANO, M.. Coração civil: a vida cultural brasileira sob o regime militar (1964-1985). Ensaio histórico. São Paulo: Intermeios, 2017.

NAPOLITANO, M. Cultura brasileira (1950-1980). São Paulo: Contexto, 2001.

NAPOLITANO, Marcos. A estranha derrota: os comunistas e a resistência cultural ao Regime Militar (19641968). In: NAPOLITANO, M.. CZAJKA, R. SÁ MOTTA, R. P. (org.). Comunistas brasileiros: cultura política e produção cultural. Belo Horizonte: Ed. da UFMG, 2013. p. 317-338.

OLIVEIRA, F de. Crítica da rąão dualista. O ornitorrinco. São Paulo: Boitempo, 2013.

ORTIZ, R. Cultura brasileira e identidade nacional. São Paulo: Brasiliense, 2012.

RIDENTI, M. Brasilidade revolucionária: um século de cultura e política. São Paulo: Ed. da Unesp, 2010.

RIDENTI, M. Em busca do povo brasileiro: artistas da revolução, do CPC à Era da Tv. São Paulo: Ed. da Unesp, 2014. 
ROCHA, G. Revisão crítica do cinema brasileiro. São Paulo: Cosac Naify, 2003.

ROCHA, G. Para Alfredo Guevara. Carta de maio 1971. In: BENTES, Ivana (org.) Glauber Rocha: cartas ao mundo. São Paulo: Companhia das letras, 1997.

SCHWARZ, R. O pai de família e outros estudos. São Paulo: Companhia das Letras, 2008.

SODRÉ, N. W. Quem é o povo no Brasil? Rio de Janeiro: Civilização Brasileira, 1962.

Data de submissão: 29/09/2020

Data de aprovação: 03/12/2020 